\title{
The Concept of Ali Abdul Halim Mahmud's Quranic Education: A Critical Analysis of 'Fundamentalist' Exegesis Paradigm
}

\author{
Mahmud Arif \\ Department of Islamic Religion Education, Faculty of Islamic Education, Universitas Islam Negeri (UIN) \\ Sunan Kalijaga, Yogyakarta 55281, Indonesia
}

\begin{abstract}
The principle of the Quran's universal relevance is understood in various ways among scholars. Such principle has led to the emergence of various perspectives. On the one hand, some consider the Quran as an open text that can continuously be reinterpreted, while on the other hand, some consider it as the ultimate book that provides guidance concerning all matters of human life. Given this context, it is of great interest to critically discuss Ali Abdul Halim Mahmud's views that considered the Quran as a comprehensive source of guidance for addressing the various problems of life as well as a text filled with a myriad of educational prescriptions. This literary study focuses on Mahmud's exegetic works by applying the holistic method based on a content analysis and a textual investigation. In his works, Mahmud affirmed that the sole solution for Muslims was returning to the guidance of the Quran and the Sunnah. According to him, the Quran serves as the primary source in understanding Islam as a Divine system that is compatible throughout the ages. He had applied two models in elaborating the Qur'anic tenets: (1) selecting a certain surah, and (2) appointing a certain educational topic. Mahmud's conviction that the perfect Quranic education system exists had prompted him to interpret Quranic verses, in clarifying

ARTICLE INFO

Article history:

Received: 28 January 2020

Accepted: 9 June 2020

Published: 25 December 2020

DOI: https://doi.org/10.47836/pjssh.28.4.49

E-mail address:

ayahandarifda@yahoo.com

and conclusive manners. His Quranic interpretation fully contains messages pertaining to morality, da'wah, and social movement in order to revive the glory of the Muslim, but frequently it lacks appreciation for critical-interpretation.

Keywords: Conclusive exegesis, education ideology, God's feast, the Quran's perfection
\end{abstract}

ISSN: 0128-7702

e-ISSN: $2231-8534$ 


\section{INTRODUCTION}

The Quran functions as the central text that its existence has been pivotal in determining the cultural formation and scientific characteristics of Muslims (Muslih, 2016). Thus, exegesis is a principal instrument in all efforts of knowledge production (Abu Zayd, 2000). Subsequently, various schools of exegeses had proliferated, given that there were differences in the epistemological preference of the exegetes and the methodological design being applied. The Quran's standing as the central text or the most authoritative text (Bennett, 2005 ) is supported by the principle that this Holy Book contains a comprehensive system of teachings to develop Islamic civilization (Al-Jundi, 1984). Despite its all-encompassing system of teachings, there are quite many Quranic verses that stimulate the human mind to dig deeper into various fundamental issues (Musa, 1985), because such system is not necessarily instantly ready-to-use.

One of the Quran's characteristics is its presence as an eternal marvel throughout the ages and as a source of guidance that we should abide by in order to overcome the various problems in life (Mahmud, 1994). Accordingly, Muslims are required continuously to explore the Quran's teachings and not be complacent with the actual results of exegeses. Unfortunately, the Quran's standing as a source of guidance in life has not been constructively appreciated due to a shallowing perspective. Firmly, Al-Ghazali (1997, p. 15) stated, "Muslims, particularly following the first century of Hijriyah, had put much emphasis on problems relating to Quranic recitals, correct recitation (tajwid) principles, and were fixated solely on the memorization of Quranic texts." As a result of a shallowing perspective, Mahmud (2000a) considered that Muslims tended to demonstrate a partial attitude in their interaction with the Quran hence dissociating them from the Islamic manhaj (perfect way).

The teachings of the Quran are believed to remain relevant regardless of the time and place (Mahmud, 1998). The principle of the Quran's universal relevance is understood in various ways. Some scholars are of the view that the Quran is a living text or an "open" text (Al-Jabiri, 2007), keeping in mind that the ideas and verses in the Quran continually engage in a dialectical process with human reasoning and greets all Muslims through the ages (Izzuddin, 2006). This point of view considers the literal writings or text of the Quran remains the same, yet the contents of its meanings are highly dynamic, developing in line with the development of its exegete's reasoning, which is dialectical with surrounding life issues.

Meanwhile, some other scholars consider the Quran as an all-encompassing text (jâmi') (Al-Jundi, 1984). Like a God's feast, the Quran is bestowed to provide nourishment for Muslims willing to accept His invitation. Quran's guidance is ready to enjoy and is filled with educational prescriptions as a manifestation of His universal and perfect way (Qutb, 2004). No one is capable of saving the Muslim community from devastation unless Muslims 
themselves hold firmly onto His manhaj that is found in the Quran and the Sunnah (Mahmud, 2005). According to Mahmud, the Quran has a myriad of unique features, of which among them are: the Quran is a form of God's feast bestowed upon humankind to obtain sufficient nourishment; it is a system that is relevant throughout all generations of humankind. Based on that opinion, he affirmed these fundamental concepts: the Quran as a comprehensive system, and it is filled with educational prescriptions. In such context, this discussion aims to analyse Mahmud's frame of thought in interpreting the Quran and in explaining its educational prescriptions.

As a thinker, an ulama (Islamic scholar) at Al-Azhar University, and an activist of the Ikhwanul Muslimin (the Muslim Brotherhood) movement in Egypt (see Lav, 2012), with an expansive scope of influence, Mahmud actively voiced the importance of elaborating God's manhaj about education, which indeed had not been much formulated by scholars. In the context of Quranic exegesis on education, his approach with two models was regarded as a distinct formulation that was not created by other prominent figures such as al-Abrasyi (d. 1981), al-Nahlawi (b. 1876), and Nasih Ulwan (d. 1987). Even his numerous studies on the Islamic education have been supported as a new referential source, particularly to activists of Quranic studies and communities oriented towards "returning to the Quran," like the Purwokerto branch of KAMMI (Association of Indonesian Muslim Students Action) in Central Java with its movement vision being much inspired by the work of Mahmud (1997) titled Perangkat-Perangkat Tarbiyah Ikhwanul Muslimin (Farida, 2014; Khalikin, 2012). From herein, the Tarbiyah movement community and the campus da'wah institution (Lembaga Dakwah Kampus) began to grow with their ideology of Islamism which has influenced the development of Islam in various universities. Such development was also followed by the expansion of the integrated Islamic schools' networking (Jaringan Sekolah Islam Terpadu) in Indonesia, and as a result, it contributed to strengthen the political Islam (Akmansyah, 2013; Fuad, 2019).

\section{METHODS}

As a literary study that attempts to construct the concept of Qur'anic education, the implementation of the holistic method, which is a method of critical thinking to capture the complete meaning, and not a mere "atomistic" meaning (Bakker \& Zubair, 1990), is based on content analysis. It uses textual investigation on Mahmud's works beginning from the problems he sought the answers to, and then the scientific efforts to delve deeper into the problems through the process of incubation, illumination through creating a dialog between the problems and various concepts and actual phenomenon, explication with analyzing and clarifying the problems, and creative synthesis with formulating new insights that are creatively combined from various theoretical and textual elements (Moutakas, 1994).

In a hermeneutic analysis, there are at least three interlinked functions in the 
efforts of understanding the contents of a holy text, namely: (1) the historical function, which is oriented to revealing textual meaning according to its historical context; (2) the meaning function, which attempts to explore its contextual meaning; and (3) the implicative meaning, which aims to elaborate the intended requirement for the current context (Gracia, 1995). Such hermeneutic analysis was utilized to observe the methodological steps of Mahmud in integrating the necessities of text meanings, the contexts, and the contextualization in order to formulate his educational exegesis. To reveal the meaningfulness of the text for education, the interpretive understanding of the Quran's guidance needs to be based on the fundamental assumption relating to Islam, which is founded on two main pillars, namely: (1) to have faith in one God and self-submission to Him alone in accordance with the provisions conveyed by His messenger; and (2) obedience to all of His commands and prohibitions (Mahmud, 1999).

\section{RESULTS AND DISCUSSION}

\section{The Educational Ideology of Mahmud}

Prof. Dr. Ali Abdul Halim Mahmud passed away on Monday, March $10^{\text {th }} 2014$, at the age of 86. He was born in Tahta, the Province of Suhaj, Egypt, in 1928, and his parents were academicians at Al-Azhar University. He was an industrious writer who had written 56 books, and he was a prominent figure to the Ikhwanul Muslimin. From a young age, Mahmud had joined Ikhwanul Muslimin, and he had been a student under the care of Imam Hasan al-Banna (d. 1949), the founder of the organization (Basaer, 2019). In Indonesia, the ideology of Ikhwanul Muslimin, as an ideology that was expressed by Mahmud, has been proven to have an expansive influence (Khalikin, 2012).

No less than twelve of Mahmud's work have been published in three languages, and they have become a part of the references collection in 23 important libraries around the world. It is not easy to gain detailed information regarding the biography and life records of this figure, especially after the Mursi administration in Egypt that was supported by Ikhwanul Muslimin had fallen and been replaced by the administration of Fattah al-Sisi. Due to very similar names, some authors consider the figure of Mahmud is the same as Syaikh Abdul Halim Mahmud (or Syaikh Mahmud), who is an expert in spiritual mysticism (tasawwuf), who was the $40^{\text {th }}$ Grand Imam of al-Azhar (see Andiko et al., 2015). Whereas, Syaikh Abdul Halim was born in 1910 and died in 1978, which is a different generation from Mahmud.

The role of education is considered as a vital and strategic part of human life. Without education, there is no dignity in human life (Mahmud, 2004). In line with the history of humankind's progress, education recognizes several schools of thought. In brief, Mahmud (2004) mapped out the schools of thought in education: the Moral School, the Intellectual School, the Religious School, the Naturalistic School, the Social School, the Political School, the Esthetic School, and the Pragmatic School. Based on those schools in education, 
Mahmud intended to place the distinctive concept of Islamic education within a broader spectrum. However, the concept of Islamic education was not much discussed within that spectrum; it was merely limited to revealing the excellence of Islamic education with some simple comparisons, instead of comparative analyses.

Some of his works about the core concepts of Islamic education are $\mathrm{Al}$ Tarbiyah Al-Ijtimâ'iyyah Al-Islâmiyyah, al-Tarbiyah al-Jamâliyyah al-Islâmiyyah, Al-Tarbiyah al-'Aqliyyah, and Al-Tarbiyah al-Khuluqiyyah, which embody his reactionary response to the schools of education above. Occasionally, Mahmud (2001) mentioned the names of Western figures who were widely influential, such as J. J. Rousseau (d. 1778) and J. H. Pestalozzi (d. 1827), but they were not positioned as "dialogue partners." He had considered that their brilliant thoughts had only emerged in the $18^{\text {th }}$ century, whereas Islam, through the Quran and the Sunnah, had formerly introduced an education system long before that century.

Mahmud's educational ideology is based on a "fundamentalist" paradigm, which refers to the uncovering of educational objectives, values, and basic principles by using the Quran and the Sunnah (Mahmud, 1996). According to him, such a paradigm is seldom used in books about education, while it is much needed by the Muslims in this modern era, which is an era for the revival of Islam and the revitalization of various religious issues. In this context, it is interesting to consider the statement made by Mahathir Mohammad (1997) that fundamentalism was a term that had been experienced a great deal of misunderstanding and it was deemed identical with terrorism, while the fact of the matter was that the best of Muslims were those who were necessarily fundamentalists, namely people who were strongly committed to following the basic tenets of Islam, such as peace.

In contrast to the concept mentioned by Mahathir, Herriot (2009) used the term fundamentalist to identify religious movements that had the following characteristics: (1) reactive since they believe that their religion is currently under the threat of modern secularism, (2) dualistic since they believe that their religious understanding is truth that stands in full opposition to enormous wickedness, (3) the supremacy of a religious source of authority (holy scripture) in regulating their beliefs and actions, (4) selective religious exegesis, and (5) millennialist historical point of view. In this case, Mahathir defined a fundamentalist as "returning to the basic principles or teachings of religion with full commitment" which had a positive connotation, while Herriot (2009, p. 2) defined it as "returning to the source of religion with one's exclusive, militant, and radical attitudes," which had a negative connotation.

Regardless of the difference in the definition of fundamentalist above, the fundamentalist paradigm (Al-Ta'ṣ̂l alShar 'î) was utilized by Mahmud to mention his approach in formulating Islamic education that was grounded on the sources of Islamic 
teaching: the Quran and the Sunnah. Both of them are believed to be the basic structure in formulating a perfect, comprehensive, and universal way of life. Nevertheless, that does not mean that the practice of ijtihâd and the willingness to adopt positive traits and practices from other civilizations are no longer deemed necessary (Mahmud, 1995). His view on the need to adopt from other civilizations is asserted in his first book on the formulation of the Islamic education concept, Al-Tarbiyah al-R̂hhiyyah, but its implementation is not much to be found in his subsequent publications. There are more or less finalistic, reactive, and dualistic features indicating his fundamentalist paradigm in elaborating the concept of Islamic education (Bruce, 2000).

Mahmud's point of view that considered the global world as being exceedingly unfair towards the Muslim community reinforced his belief of the urgency to have an Islamic education concept for the sake of humankind (Mahmud, 1995), and this is in line with the exclusive-reactive reasoning model that he developed as a response to the modernization of his community and the pressure of negative influences from the West. Modernization and negative influences from the West had led to two grave problems, namely the deideologization of Islam and the colonization of the Islamic world. Both of these problems have weakened and tormented the Muslims. These problems remain unmanageable on account of Muslims, not putting the Quran and the Sunnah to use as their guidance in life (Mahmud, 2001).
The model of Mahmud's reasoning was found its correlation and similarity in the fundamentalist ideology of Sayyid Qutb (d. 1966), one of the figures of Ikhwanul Muslimin, who firmly stated, "Islam does not allow Muslims to learn the bases of their creed and the basic tenets of its ideology; the interpretation of the Quran, hadith, or the history of the Prophet... the political manhaj and other similar fields, from non-Islamic references, even though they have an extremely consistent level of piousness and religiosity" (Qutb, 2009, p. 246). Mahmud and Qutb had developed a model of reasoning that was based on the underlying assumption that the Quran and the Sunnah were the solutions to disputes among the various schools of thought, and that non-Islamic references were a representation of ignorance that was impossible to amalgamate with the two sources of Islamic teachings to conclude.

\section{Mahmud's Approach to Interpreting the Qur'an}

The Quran is widely believed to have a distinctive and unique status in the life of Muslims. It has prepared a comprehensive and perfect system (manhaj). Accordingly, every Muslim must explore and formulate this manhaj so that it can be utilized as a useful guide in living life and responding to all problems in life. Mahmud (1999, p. 214) firmly said, "the Quran and the Sunnah must be obeyed, keeping in mind that both are well-defined and comprehensible texts that neither neglect nor leave matters of life and death unexplained to the Muslim 
community." Through such a statement, Mahmud (2005) had intended to build up people's faith in the Quran's perfection.

The belief of the Quran's perfection is embraced by the majority of the Muslim community, yet in practice, they tend to stay away or be alienated from the Quran. They would prefer other thoughts and ideologies that do not align with the teachings of Islam instead. One of the evidence for this is the fact that the Ikhwanul Muslimin movement, which firmly upholds this belief, has often been opposed and considered hostile. What this organization has to offer is analogous to drops of water that continue to drip and flow from its source, and they will inevitably fall upon an appropriate patch of land subsequently capable of cultivating remarkable plant life (Mahmud, 2005).

According to Mahmud (1999), Islam is a divine system and order. Elaborations of the system and order can be found in the Quran and the Sunnah. If the Muslim community, as of current, is still incapable of establishing a proper and comprehensive system of life, then this would, in most part, be caused by their attitude of alienating themselves and turning their back from the Quran and the Sunnah. Any actions conducted outside of the God-given way of life are clear indications of disbelief ( $k u f r$ ), and they may indistinctly be identified as hypocritical (nifâq). When interpreting surah Al-Mâ'idah/5: 44, for instance, Mahmud (1994) underlined the strong message in this verse, which was that people who had abandoned God's law were unbelievers for having denied God and His law. The
Muslim community is thus confronted with two options: to believe wholeheartedly or to deny entirely, and in this case, partial denial is considered as full denial (Mahmud, 1998).

Given that Islam is Allah's way (manhaj), then Islam surely has a manhaj for education. According to Mahmud (1995), the most fundamental problem confronted by the Muslim community on this day is the lack of an Islamic education system. The development of an Islamic education system must be based on the Quran and the Sunnah. Nevertheless, this does not mean that Muslim intellectuals are forbidden to gain benefits from other cultures, thoughts, and ideas of prominent figures, so long as it does not violate the provisions stipulated in the Quran and the Sunnah. Mahmud (2001) appreciated the significance of the empirical-deductive method in order to develop an Islamic education system, such as the descriptive method, experimentation, and the historical method that underlied the scientific investigation process. However, an additional aspect is required to appreciate those methods, namely the intention of obtaining Allah's blessing by considering Islamic morality, for instance: sincerity, honesty, and the goal of achieving a good life. Unfortunately, his thoughts regarding the possibility of adopting other cultures/ thoughts and the significance of appreciating the scientific method to develop an Islamic education system seem to be obscured by his tendency of reinforcing perspectives about the Quran's perfection.

Such opinion illustrates the model of ideological Islam he carried, which is 
the aspiration of an Islamic group that has been fighting hard for the sake of upholding Islamic sharia. To this Islamic group, upholding Islamic sharia is no mere obligation; it is also a necessity in order to resolve the numerous problems afflicting the contemporary Muslim community. Returning to the Quran and the Sunnah is the first and foremost demand that continues to be advocated since it is believed to be the root of the solution and the basis of ideology. The narrow understanding of the slogan "Returning to the Quran and the Sunnah" advocated by the ideological Muslim group confronts various oppositions. Muhammad Imârah (2004), for example, criticized the ideological perspective of hâkimiyyah ilâhiyyah (absolute sovereignty of God's law) which he considered "extreme" as it was unable to distinguish between definite, clear, and stringent (qat' 'iy) Islamic laws that were contained in the Quran and the Sunnah, and Islamic laws that were of ijtihâdi (reasoning) character. Concerning the first type of law, we cannot instantaneously consider those who do not abide by it as unbelievers, even more so concerning the second type of law.

As evidence of Mahmud's ideological perspective, we can conduct a slight comparative analysis between Mahmud's interpretation and Syaikh Abdul Halim Mahmud's interpretation (d. 1978), who had both elaborated the contents of Qs. Ali Imran/3. Syaikh Mahmud (2000) was willing to cite the opinions of several orientalists whom he regarded as objective individuals who affirmed the truth of the fundamental principle in the teachings of the Quran, namely that shari'a was enforced under principles of justice, morality was based on principles of love and affection, and faith was founded on principles of justice, love, affection, and comradery that were embodied in the teachings of tawhid (oneness of God). In this case, Syaikh Abdul Halim underlined the basic principles of Quranic teachings that were substantive and inclusive.

Contrastingly, Mahmud (1998) in his elaboration broadly highlighted the Quranic teachings as a manifestation of Allah's way, which possessed exclusive uniquities, when compared to other holy texts, namely: (1) it is the ultimate and final text that God has guaranteed to be under His auspices to maintain; (2) it serves as a "control" and standard (muhaiminan) for the other texts; (3) it is the most perfect and comprehensive text; (4) all worldly and religious matters are contained in it; (5) the Quran was indeed set to be the ultimate holy text as a guidance for humankind; (6) the Sunnah functions to provide more detailed elaborations of the Quran's global contents; (7) the Quran is filled with educational prescriptions keeping in mind that it is God's feast, as ascertained in the Prophet's hadith narrated by alDârimî; (8) there is an education system within the Quran that is characterized as being derived from God, comprehensive, always relevant no matter the time and 
place; and (9) introduction of the scope of Quranic education system that covers individual human, family, community, and nation.

Mahmud's perspective and orientation is to raise awareness among and move the Muslim community so that they would try and improve themselves together through joint efforts. Education and $d a$ 'wah (religious preaching) are two critical media required in order to develop awareness and social movement, outside the realms of politics. In terms of hermeneutical analysis, Mahmud had the role of shaping and producing the meanings of the Quranic verses being interpreted (see Fa'âli et al., 2011). In terms of methodology, the role of producing the meanings of verses is supported by the view that acknowledges the need to carry out ijtihâd in two areas: in matters that no text is found and when no text description is found, implying that it is not clear and stringent or sarîh, which is required by the true principle of takwil (text description) (Mahmud, 1999).

Most of Mahmud's interpretations of the Quranic verses were results of his hermeneutical process (ijtihâd) since concerning the interpretations, he attempted to elaborate and define the verses that have not been explicit according to the model that he employed. Interpreting one verse with another, associating them with relevant hadith narrations, and citing the opinions of some prominent ulama were a part of the methodological implementation of the said model. The ideological implementation is indicated by his interpretation that is oriented towards the efforts in raising the Muslim community's awareness to return to the path of Allah, in pumping their spirit of struggle to continue preaching and engaging in social movements, and in igniting their flame to incite in them the courage to fight all kinds of disbelief by prioritizing nonviolent approaches.

He continuously emphasized the existence of a consecutive (sequential and interconnected) relationship among Allah, the Quran, and the happiness of humankind. It means that in achieving happiness in life, human beings are required to return to the Quran, and the Quran is a manifestation of Allah's manhaj. In this opinion, Qutb (2004, p. 510), one of the figures of Ikhwanul Muslimin, firmly stated, "Living with the Quran is living with Allah...when a person lives with [along the path of] the Quran, that person lives with [along the path of] Allah... Thus, Muslims need to engage in interactions with the Quran bearing in mind that it is a guide for humans to live this life".

Based on such perspective, Mahmud and Qutb both underlined the importance of an education system capable of transforming belief into actual life behavior in order to achieve the goal of developing a Muslim community that was structured under God's law (Qutb, 2004; Mahmud, n.d.). It is an education system that can guide humankind to achieve their goals in life: (1) to believe in the oneness of Allah and to worship only Him by the guidance of sharia, (2) to abide by the manhaj of the Quran and the Sunnah in living life, and (3) to spread prosperity throughout the earth and advance towards 
a better life for humankind (Mahmud, n.d.). Here, Mahmud presented two kinds of argumentations on the urgency of Islamic education, namely: a positive-affirmative argument that declares the perfection of the Quran's manhaj as a basis for education and a contrary argument that tends to reject the adequacy of other sources which do not return to the Quran.

\section{Application of Mahmud's Approach in Interpreting Quranic Verses}

Islam is the religion of truth, guidance, tolerance, and good social relations. Accordingly, Islamic education is the pillar that supports those Islamic values. With a proper education system, Islam will be able to resolve the various problems of life faced by humankind (Mahmud, 2002). Such conviction had reinforced Mahmud's intent to try and formulate a comprehensive Islamic education concept because education is considered as a fundamental Islamic endeavor. As an individual who was active in $d a$ 'wah activities in numerous places and the community of Ikhwanul Muslimin, Islamic education had seized his attention for nearly fifty years (Mahmud, 1995).

According to Mahmud (2001), the relation between Islam and the education system can be described through the Islamic teaching that calls to "Learn, Be Knowledgeable, and Teach," and the Islamic mission of producing a generation that can contribute to the development of Islamic human civilization. An education system can be considered as "Islamic" when it is enforced upon these three essential foundations, namely (1) a system of faith in monotheism, (2) a proper system of worship by provisions in the Quran and the Sunnah, and (3) a system of morality provisioned by Islam (Mahmud, 1995; see Embong et al., 2017). Based on this point, Mahmud (1995) viewed Islam as an eternal, universal, and ultimate teaching. The actualization of Islamic teachings requires an "Islamic" education system that aims to: (1) form proper faith, (2) teach proper worship, (3) cultivate the spirit of mutual understanding among human beings, (4) spread the spirit of mutual help, (5) work hard for the sake of making the earth prosperous, (6) teach people to have a firm attitude, (7) teach people to foster an Islamic household, (8) form a social spirit, (9) form individuals that are nationalistic, (10) form individuals that maintain Islamic ideology, (11) form individuals that actively engage in $d a$ 'wah and (12) form individuals that can take part in Islamic movements.

As a system, Mahmud (1995) attempted to formulate elements of Islamic education covering its: (1) definition and feature, (2) objective, (3) means/media, (4) source/ foundation, (5) scope, and (6) method. Upon close examination of Mahmud's works, there are two approaches that had been used to formulate an education system based on the Quran, namely: (1) selecting a specific verse to interpret on its educational meanings, and (2) raising particular educational theme and describing 
relevant contents of Quranic verses. His assumption, there is not a single matter in human life overlooked by the Quran.

In line with the employed underlying assumption, i.e., Islam is an ultimate religion, and that there is no salvation other than Islam, Mahmud (1999, p. 160) interpreted the content of Qs. Ali Imran/3: 85 as follows, "And whoever desires other than Islam as religion, never will it be accepted from him, and in the Hereafter, he will be among the losers."

All adherents of any religion are required to embrace Islam that was brought by the Prophet Muhammad, as there is no other religion that is accepted except Islam. If they reject embracing Islam, in the Hereafter, they will be included among the losers and punished, as firmly stated in the Prophet's hadith narrated by Muslim. Following the advent of the Prophet, any religion other than Islam will not be accepted (Mahmud, 2000b). According to Mahmud, the Muslim community should always be cautious of the efforts made by a group of people, be it Muslims or non-Muslims, who intend to mislead the Muslim community with their idea that there is salvation outside of Islam.

Mahmud's interpretation is different from the interpretations of several contemporary Muslim thinkers, such as Shahrur and Husein Fadlullah. They interpreted Islam not merely limited to the followers of Muhammad PBUH (Shahrur, 1996). Generically, Islam encompasses all heavenly messages that demonstrate total submission to God, not only Islam, as the religion revealed by the Prophet
Muhammad (Rakhmat, 2006). Meanwhile, Syaikh Mahmud (2000) and Hawwa (1981) interpret the word Islam in the above verse by not referring to a specific individual, a specific race, a specific place, and a specific time. The word Islam refers to a universal meaning, not solely limited to Muhammad's message. However, for the current context, the true manifestation of Islam is no longer found except within the Quran and the Sunnah (Mahmud, 1998), because the teaching of "Islam" revealed by the previous messengers had been forgotten or replaced (Hawwa, 1981).

Despite its exclusive interpretation, Mahmud did not justify acts of violence or compulsion in acceptance of religion. When interpreting the subsequent verses concerning the case of apostasy, he had not at all mentioned any possibility of death to apostates who has no intention of repenting as stipulated by the law formulated by most experts of Islamic jurisprudence. By using the perspective of $d a$ 'wah and movement, Mahmud (1998) advocated the importance of sacrificing one's self or continuing the struggle using one's material wealth, time, sincerity, and perseverance in facing the challenges posed by the oppositions of Islam. In this case, he had put morality at the forefront so that the belief in the absoluteness of Islam does not cause people to judge others or react harshly to them quickly.

A firm and strict attitude to the enemies of Islam still needs to be shown. The obligation to engage in jihâd is gradually required (Mahmud, 2000b), which implies that it 
should be understood comprehensively. In the final stage of the command to engage in jihâd, the Muslim community is required to fight against all unbelievers without exception in order to free humankind from shirk (polytheism) (Qs. Al-Tawbah/9: 36), and to uphold values of humanity through various means, among others: self-readiness and preparation, sacrificing one's wealth, body, and soul on the battlefield, education and $d a$ 'wah activities (Mahmud, 2000b). Mahmud's elaboration regarding gradations in command of jihâd indicates that he did not interpret Quranic verses that called for war and Quranic verses that contained messages of peace in the framework of naskh (abrogation) or the framework of particular and universal provisions. Jihâd, wherein one of the conducts is to fight against the enemies of Islam, is indeed an eternal obligation until the end of time (Mahmud, 2000b). The educational message, religious militancy development is necessary so that individuals have a high spirit of struggle in spreading the word of Islam with all the challenges that must be confronted (Mahmud, 1998).

When the condition of the Muslim community is weak and incapable of putting up a fight against the infidels, then there are only two options available: momentary dissimulation or denial of religious belief as long as it does not sacrifice truth, strengthen falsehood, and resemble hypocrisy (Mahmud, 1998). Aside from infidels, Muslims are also required to be ready to confront opponents of truth, namely (1) group of people who deny the truth of religious teachings, (2) group of people who deny the prophecy of Muhammad, (3) group of people who believe in Allah and the Prophet, but they have the opinion that the teachings of the Prophet only regulates religious, not worldly matters, and that he did not establish a government, (4) group of people who deny the teachings of the Prophet concerning the faith in the unseen, (5) group of people who deny the ability of the Prophet's teachings to overcome various problems of life (Mahmud, 1998).

Several core adages presented by Mahmud, for instance: jihâd (great effort for virtue), hijrah (departure from badness), taqiyyah (keeping faith a secret), and enemies of Islam, are concrete evidence that he did bear an understanding of Islam as an ideology that has various empirical manifestations, from those that are soft and academic to those that indicate extremist and terrorist features. Based on Desai's (2007) theory, Mahmud's understanding of ideological Islam is demonstrated by moral and political orientations. His moral orientation is apparent in his strong will to enforce a more pious lifestyle for the Muslim community, while his political orientation is described through his strategy of fighting for the glory of Islam and the enforcement of his system of teachings in regulating all aspect of human life (see Musa, 1980).

Mahmud's interpretation model of the Quranic verses can be seen as a manifestation of the hermeneutics of enquiry that attempts to explore the contents of the meanings in the Quran in order to elaborate its prescriptions and to formulate its educational perspective. 
His interpretation model is founded on the underlying assumption of the holy text's clarity, the ability of the holy text in providing a comprehensive system (see Thiselton, 1992), and the critical-corrective function of the teachings in the holy text regarding the existing education reality. Using this frame of thought, Mahmud had been proven to be successful in explaining the various aspects of educational contents in the Quranic verses through a conclusive interpretation model, i.e., a claim of sufficient interpretation to a Divine system that is comprehensive and applicative for human life.

In the hermeneutical analysis, conclusive interpretation should be given a critical note, bearing in mind that it does not pay much attention to the historical elements in the interpretation, even more so with "interpreted" historicity. Recognizing the historical aspect encourages open attitude towards contextualization, dialectics, and interpretation criticism so that no matter how a complete an interpretation model is, it will still be considered relative when situated within the context of the Quran's absoluteness. Recognition of the historical aspect sees the interpreted text as a living experience (tajribah hayyah). Thus, it is not enough to merely have the ability of linguistic mastery and the context of the socio-cultural settings, because mastery in the aspect of dynamic Muslim community benefits is also required (Hanafi, 2004).

By referring to Dayyâb's (2005) opinion on the mapping of Islamic discourse, particularly in the Egyptian, into Radical
Islam, Islam Left, Islamization of Knowledge, Islamic Hermeneutics, and Independent Islamism Groups, Mahmud's interpretation model can thus be categorized into the independent Islamism groups which are affiliated mainly with the Ikhwanul Muslimin (see Baker, 2003). That can at the very least be observed from: (1) his elaboration of some jargons of radical Islam, such as hijrah and jihâd, with a style of language that is relatively lenient as he employed a nonviolent approach (Mahmud, 1994), and (2) his elaboration on the Islamic education system is based on the Quran in order to renovate the modern education system that he considered as being muddled.

As a figure of Ikhwanul Muslimin, Mahmud (1997) appreciated the success of the organization in offering the concept and practice of Islamic education through a distinctive, particular, and unique education system compared to other organizations' education system. The issue of Christianization in Egypt, secularism, westernization projects, accusations of the Islamic system's inability to follow modern life, and various pressures on the Ikhwanul Muslimin had influenced his perspectives in describing the education system within the mind frame of Islamic teachings' universality, nobility, and perfection.

\section{CONCLUSION}

Mahmud persistently developed his conviction on the perfection of the Quran and the obligation that Muslims have to abide by it. He viewed that there was no other way for the Muslim community that 
was situated in the middle of a misleading, destructive, and flawed cultural, ideological suppression, except to return to the guidance of the Quran and the Sunnah. The Muslim community that has not been able to establish an excellent and comprehensive system of life is a result of their attitude, which is contrary to the guidance of the two sources above.

Mahmud used two models in elaborating the content of the Quran, namely: (1) selecting certain verses then the educational meanings were interpreted, and (2) raising specific educational themes and elaborate the contents of relevant Quranic verses. The two models originate from his fundamentalist ideology that affirms the excellence of an education system based on the noble, perfect, and universal path of God. By using the first model, he attempted to develop a theoretical framework by analyzing the main contents of Quranic verses. Meanwhile, using the second one, he tried to create a dialogue between issues of education and life using prescriptions from the Quran.

His educational perspective seems to firmly head towards reinforcing the function of the Quran as guidance for Muslims in dealing with all aspects of life. In line with such fundamentalist view, he was more inclined to develop a clarifying interpretation that responds to misunderstandings about the Quran and acts that discredit Islam, a semi-exclusive interpretation that elaborates the excellence of Islamic teachings in comparison to other system of teachings, and conclusive interpretation that promotes the perfection of the Quran and the Sunnah. Conclusive interpretation lacks appreciation for the historical aspects of interpretation that are necessary to establish an open attitude to contextualization and critical-interpretation.

\section{ACKNOWLEDGEMENT}

The researcher would like to thank the Rector of State Islamic University Sunan Kalijaga for supporting this study and the reviewers for their useful comments.

\section{REFERENCES}

Abu Zayd, N. H. (2000). Mafhûm al-Nașṣ: Dirâsat fi 'ulûm al-Qur'ân [Text concept: Study of the Quran sciences]. Beirut, Lebanon: al-Markaz al-Thaqafi al-'Arabi.

Akmansyah, M. (2013). Metode pendidikan ruhani perspektif al-Qur'an [Methods of spiritual education from the Quran perspective]. Ijtimaiyya, 6(2), 97-112.

Al-Ghazali, M. (1997). Berdialog dengan al-Qur'an [Making a dialogue with the Quran] (M. Hakim, Trans.). Bandung, Indonesia: Mizan.

Al-Jabiri, M. A. (2007). Al-Madkhal ilâ al-Qur'ân al-Karîm: Fi al-ta'rîf bi al-Qur'ân [Introduction to the noble Quran: Preliminary remarks on the Quran] (Vol. 1). Beirut, Lebanon: Markaz Dirâsât al-Wahdah.

Al-Jundi, A. H. (1984). Al-Qur'ân wa al-manhaj al- 'ilmî al-mu'âșir [al-Quran and contemporary scientific methods]. Cairo, Egypt: Dar al-Ma'arif.

Andiko, T., K. el-Wardah, \& Fauzan. (2015). Teori responsibilitas dan prioritas dalam penalaran fiqih untuk merealisasikan maqasid al-syari'ah: Studi komparatif pemikiran Ali Abdul Halim Mahmud dan Yusuf al-Qardhawi [The theory of responsibility and priority in the fiqh reasoning 
to realize the shari'a aims: A comparative study of thoughts of Ali Abdul Halim Mahmud and Yusuf al-Qardhawi]. Manhaj Jurnal Penelitian \& Pengabdian Masyarakat IAIN Bengkulu, 3(1), 20-32.

Baker, R. W. (2003). Islam without fear: Egypt and the new Islamists. Cambridge, England: Harvard University Press.

Bakker, A., \& Zubair, A. C. (1990). Metodologi penelitian filsafat [Philosophy research methodology]. Yogyakarta, Indonesia: Kanisius.

Basaer. (2019). Al-Âlim al-murabbî Ali Abdul Halîm Mahmûd fî dzimmatillâh (1928-2014) [The charismatic scholar and educator Ali Abdul Halim Mahmud passed away]. Retrieved July 4, 2019, from https://basaer-online.com/?p=6546

Bennett, C. (2005). Muslims and modernity: An introduction to the issues and debates. London, England: Continuum.

Bruce, S. (2000). Fundamentalism. Cambridge, England: Polity Press.

Dayyâb, M. H. (2005). Al-Islâmiyyûn al-mustaqillûn: Al-huwiyyah wa al-su'âl [Independent Islamist figures: Identity and discussion]. Cairo, Egypt: Maktabah al-Usrah.

Desai, M. (2007). Rethinking Islamism: The ideology of the new terrorism. London, England: I.B. Tauris.

Embong, R., Abdullah, R. T., Talib, M. T. A., Ismail, F. Z., Sulaiman, R. H. R., \& Noor, M. H. M. (2017). Philosophical foundations and their implication on Islamic education. Pertanika Journal of Social Sciences and Humanities, 25(S), 57-70.

Fa'âli, M. T., Qattan, A., Fayduh, A. Q., Abuhait K., Baheshti, A., Larijani, S., \& Jarradi, S., (2011). Al-Ta'wîl wal herminiutîâa: Dirâsât $f$ âliyyât al-qur'ân wa al-tafsîr [Interpretation and hermeneutics: Studies in the mechanisms of reading and interpretation]. Beirut, Lebanon: Markaz al-Haḍârah li Tanmiyat al-Fikr al-Islâmî.
Farida, U. (2014). Peran Ikhwanul muslimin dalam perubahan sosial politik di Mesir [The role of Muslim Brotherhood in political social change in Egypt]. Jurnal Penelitian, 8(1), 45-70.

Fuad, A. F. N. (2019). Kajian literatur tentang perkembangan historis dan transformasi dakwah gerakan tarbiyah di Indonesia [Literature review on historical development and da'wa transformation of tarbiyah movement in Indonesia]. Jurnal Lektur Keagamaan, 17(2), 349-382.

Gracia, J. E. (1995). A theory of textuality: The logic and epistemology. New York, USA: State University of New York.

Hanafi, H. (2004). Hiṣ̂ar al-zaman: Al-hâạir [Blockades of time: The present]. Cairo, Egypt: Markaz al-Kitâb li al-Nashr.

Hawwa, S. (1981). Al-Islâm [Islam] (Vol. 1). n.p.

Herriot, P. (2009). Religious fundamentalism: Global, local, and personal. London, England: Routledge.

Imârah, M. (2004). Maqâlât al-ghuluw al-dînî wa allâ dîn $[$ [Discussion on religious and non-religious extremism]. Cairo, Egypt: Maktabah al-Shurûq al-Dauliyyah.

Izzuddin, N. (2006). Al-Haqîqah min haqâi'q alQur'ân al-maskût 'anhâ [Hidden realities of the Quran]. Cairo, Egypt: Maktabah Madbouli.

Khalikin, A. (2012). Ikhwanul muslimin dan gerakan tarbiyah di Banten dan Batam [The Muslim brotherhood and educational movements in Banten and Batam]. Harmoni Jurnal Multikultural \& Multireligius, 11(2), 53-71.

Lav, D. (2012). Radical Islam and the revival of medieval theology. Cambridge, England: Cambridge University Press.

Mahmud, A. A. H. (n.d.). Al-Tarbiyah al-khuluqiyyah [Moral education]. Cairo, Egypt: Dâr al-Tawzi' wa al-Nashr. 
Mahmud, A. A. H. (1994). Al-Tarbiyah al-islâmiyyah fi sûrat al-Mâidah [Islamic education in the sura of al-Mâ'idah]. Cairo, Egypt: Dâr al-Tawzi’ wa al-Nashr.

Mahmud, A. A. H. (1995). Al-Tarbiyah al-ruhiyyah [Spiritual education] Cairo, Egypt: Dâr al-Tawzi' wa al-Nashr.

Mahmud, A. A. H. (1996). Al-Tarbiyah al-'aqliyyah [Intellectual education]. Cairo, Egypt: Dâr alTawzi' wa al-Nashr.

Mahmud, A. A. H. (1997). Perangkat-perangkat tarbiyah Ikhwanul muslimin [Educational equipment of the muslim brotherhood] (W. Ahmadi, Trans.) Solo, Indonesia: Era Intermedia.

Mahmud, A. A. H. (1998). Al-Tarbiyah al-islamiyyah fi sûrat Ali Imrân [Islamic education in the sura of Ali Imran]. Cairo, Egypt: Dâr al-Tawzi’ wa al-Nashr.

Mahmud, A. A. H. (1999). Al-Tarbiyah al-islâmiyyah fi surat al-Nisâ [Islamic education in the sura of al-Nisa]. Cairo, Egypt: Dâr al-Tawzi' wa al-Nashr.

Mahmud, A. A. H. (2000a). Al-Tarbiyah al-diniyyah al-ghâ'ibah [The lost religious education]. Cairo, Egypt: Dâr al-Tawzi' wa al-Nashr.

Mahmud, A. A. H. (2000b). Al-Tarbiyah al-islâmiyyah fi surrat al-Tawbah [Islamic education in the sura of al-Tawbah]. Cairo, Egypt: Dâr al-Tawzi’ wa al-Nashr.

Mahmud, A. A. H. (2001). Al-Tarbiyah al-ijtimâ 'iyyah al-islâmiyyah [Islamic social education]. Cairo, Egypt: Dâr al-Tawzi' wa al-Nashr.

Mahmud, A. A. H. (2002). Al-Tarbiyah al-iqtiṣâdiyyah al-islâmiyyah [Islamic economic education]. Cairo, Egypt: Dâr al-Tawzi’ wa al-Nashr.

Mahmud, A. A. H. (2004). Al-Tarbiyah al-islamiyyah fi al-mujtama' [Islamic education in society]. Cairo, Egypt: Dâr al-Tawzi wa al-Nashr.
Mahmud, A. A. H. (2005). Al-Tarbiyah al-islâmiyyah fi al-bayt [Islamic education in family]. Cairo, Egypt: Dâr al-Tawzi wa al-Nashr.

Mahmud, S. A. H. (2000). Tafsîr sûrat Ali Imrân [Interpretation of the sura of Ali Imran]. Cairo, Egypt: Dâr Gharîb.

Mohammad, M. (1997). Islam: The misunderstood religion. Journal of Islamic Studies, Oxford, 36(4), 697-705.

Moutakas, C. (1994). Phenomenological research methods. London, England: SAGE Publications.

Musa, M. Y. (1980). Al-Islâm wa hâjat al-insân ilaih [Islam and human necessity to it]. Kuwait City, Kuwait: Maktabah al-Falâh.

Musa, M. Y. (1985). Al-Qur'ân wa al-falsafah [The Quran and philosophy]. Cairo, Egypt: Dar alMa'arif.

Muslih, M. (2016). Al-Qur'an dan lahirnya sains teistik [The Quran and the birth of theistic sciences], Tsaqafah Jurnal Peradaban Islam, 12(2), 257-280.

Qutb, M. (2004). Dirâsât Qur'âniyyah [The Quranic studies]. Cairo, Egypt: Dar al-Shurûq.

Qutb, S. (2009). Ma'âlim fi al-tharîq (petunjuk jalan yang menggetarkan iman) [Inspiring guidance for stepping on the way] (M. Harun, Trans.). Yogyakarta, Indonesia: Darul Uswah.

Rakhmat, J. (2006). Islam dan pluralisme: Akhlak al-Qur'an menyikapi perbedaan [The Quranic ethics in dealing with diversity]. Jakarta, Indonesia: Serambi.

Shahrur, M. (1996). Al-Islâm wa al-îmân: Manzûmat al-qiyam [Islam and faith: Values system]. Damascus, Syria: al-Âhâli li al-Ṭibâ'ah.

Thiselton, A. C. (1992). New horizons in hermeneutics. Michigan, USA: Zondervan Publishing House. 